Didáctica Geográfica nº 21, 2020,pp. 75-95

DOI: https://doi.org/10.21138/DG.541

ISSN electrónico: 2174-6451

\title{
THE THEMATIC CARTOGRAPHY OF GALICIA AS A PRO- MOTER OF CULTURAL TOURISM AND AS A TEACHING AID FOR GEOGRAPHY
}

\author{
LA CARTOGRAFÍA TEMÁTICA DE GALICIA COMO PROMOTORA DEL TURISMO \\ CULTURAL Y DE UNA SOLUCIÓN DIDÁCTICA EN LA GEOGRAFÍA
}

LA CARTOGRAPHIE ThÉMATIQUe de la GALICE EN TANT QUE PROMOTEUR DU TOURISME CULTUREL ET D'UNE SOLUTION DIDACTIQUE EN GÉOGRAPHIE

Yamilé Pérez Guilarte

Universidade da Coruña

yamile.perez@udc.es

Francisco Xosé Armas Quintá

Universidade de Santiago de Compostela

francisco.armas@usc.es

Xosé Carlos Macía Arce

Universidade de Santiago de Compostela

carlos.macia@usc.es

Recibido: $31 / 05 / 2020$

Aceptado 09/09/2020

\section{Abstract:}

The article presents a sample of the thematic cartography that will be integrated into the Observatory of the Cultural Heritage of Galicia platform, a digital application in a website and App format. The proposed thematic cartography provides relevant 
information about the region's heritage, demographics, and socioeconomic aspects for visitors undertaking cultural tourism in Galicia. Moreover, it provides a vital didactic resource for the teaching-learning of geography from an active, reflective and critical perspective, at all levels of education from primary education through to university.

\section{KEYWORDS:}

Didactics of geography; thematic cartography; ICT resources; heritage; cultural tourism.

\section{RESUMEN:}

El artículo presenta una muestra de la cartografía temática que será integrada a la plataforma del Observatorio del Patrimonio Cultural de Galicia, una aplicación digital en formato de página web y de App. La cartografía temática propuesta aporta información patrimonial, demográfica y socioeconómica relevante para los visitantes que realicen turismo cultural en Galicia. Además, constituye un recurso didáctico vital para la enseñanza-aprendizaje de la geografía desde una perspectiva activa, reflexiva y crítica, en los diferentes niveles educativos a partir de la educación primaria y hasta la universitaria.

\section{Palabras clave:}

Didáctica de la geografía; cartografía temática; recursos TIC; patrimonio; turismo cultural.

\section{RESUMÉ:}

L'article présente un échantillon de cartes thématiques préparées pour être intégrées dans la plate-forme de l'Observatoire du Patrimoine Culturel de Galice, une application numérique sous la forme d'un site web et d'une application. La cartographie thématique proposée fournit des informations patrimoniales, démographiques et socioéconomiques pertinentes pour les visiteurs qui font tourisme culturel en Galice. En outre, il constitue une ressource didactique vitale pour l'enseignement-apprentissage de la géographie d'un point de vue actif, réfléchi et critique, aux différents niveaux éducatifs à partir de l'enseignement primaire et jusqu'à l'université.

\section{MotS-CLÉS:}

Didactique de la géographie; cartographie thématique; ressources TIC; patrimoine; tourisme culturel. 


\section{INTRODUCTION}

In recent years, there has been a notable surge in society's interest in tangible and intangible heritage and in the desire to become more acquainted with people's history and cultural values. This interest can be observed in the way that cultural assets are consumed, for example, in the popularity of movies, television series, novels or comics set in times of major historical events (Rivero, 2006). It is also reflected in the growth of cultural tourism and in the emergence of new forms of tourism such as creative, experiential or community tourism (Smith, 2006; Ruiz et al., 2008; Chang, Backman \& Huang, 2014, Richards, 2018). A particular aspect of these forms of tourism is the desire to gain a familiarisation with the traditions and ways of life of different cultures through a more active and closer interaction with local residents. Therefore, it could be stated that all these modalities form a part of cultural tourism.

In this context, it is essential to manage the local heritage in a manner that prioritizes the appreciation of this heritage and knowledge of territorial realities. The use of Geographic Information Technologies (Buzo Sánchez, 2015; De Miguel González, 2016; Membrado, 2016) facilitates the location, dissemination, and access to information about cultural heritage. However, if combined with thematic cartography, these technologies acquire a greater importance by introducing a variety of socioeconomic variables that provide a more holistic understanding of cultural and territorial dynamics.

This way, it is possible to think about the design of Heritage Information Systems that have a multifunctional character. From a tourism point of view, they can offer visitors access to geolocation information and to relevant socio-economic data about the cultural sites that are of interest to them. This would contribute to the promotion of cultural tourism with a strong educational component, which is especially relevant if we consider the benefits of informal education, that are becoming increasingly acknowledged (Asensio \& Pol, 2020).

In formal education, these systems can also offer an extremely valuable learning resource at all educational levels from primary education through to university. In particular, for the teaching-learning of geography, they would allow us to move beyond the simple location of physical elements. Instead, they would enable us to interpret different behaviours based on an understanding of their conditioning variables.

Likewise, they can become a tool that aids comprehensive territory management, which could facilitate decision-making for policy makers when planning for sustainable territorial development, from the social, economic and environmental perspective (Pérez Guilarte \& Lois González, 2018). They would, moreover, contribute to enhancing the local population's appreciation and awareness of their heritage, as well as promoting citizen participation processes. 
The purpose of this article is to disseminate an example of the thematic cartography of Galicia that will be integrated into the Observatory of the Cultural Heritage of Galicia platform, a digital application in website and App format for educational, tourism, and heritage management purposes, which also encourages citizen participation.

\section{CONCEPTUAL FRAMEWORK}

\subsection{Cultural tourism and heritage teaching}

As the World Tourism Organization states, cultural tourism is a growing trend worldwide, which encompassed over 39\% of total international tourism arrivals in 2017 (UNWTO, 2018). An extensive offer of tourism modalities has emerged based on tangible and intangible heritage and contemporary cultures, such as heritage, gastronomic, creative, experiential and community tourism (Richards, 2018). As a response to current transformations in cultural tourism, the UNWTO adopted the follow recent definition:

Cultural tourism is a type of tourism activity in which the visitor's essential motivation is to learn, discover, experience and consume the tangible and intangible cultural attractions/products in a tourism destination. These attractions/products relate to a set of distinctive material, intellectual, spiritual and emotional features of a society that encompasses arts and architecture, historical and cultural heritage, culinary heritage, literature, music, creative industries and the living cultures with their lifestyles, value systems, beliefs and traditions (UNWTO, 2018, p. 95).

As we can be discerned from the above definition, the practice of cultural tourism becomes an extremely valuable source of knowledge about the tangible and intangible heritage of the places visited. Hence, the leisure trips that students take in their family environment forms a part of what has been called informal education. Informal learning is one that does not make the fundamental learning intention explicit. It does not usually take place either in the classroom or in places that the learner perceives as rigidly structured. On the contrary, it takes place in a context of cultural leisure during a relaxing and interesting activity, which implies a prior motivation of the students and that they can connect to or disconnect from at their discretion (Hodkinson, Colley \& Malcolm, 2003).

In recent years, we have indeed become aware that, in the formal context, despite all efforts and explicit objectives, on many occasions, students do not learn. Whereas, in informal contexts, people acquire knowledge despite this not being the primary intention (Asensio \& Pol, 2002). However, this is not simply about limiting this approach to the physical context. For example, formal learning activities can be designed outside the 
classroom, such as school trips to monuments, historical sites or museums (Benejam \& Tomàs, 2003; Molina, 2010, Molina 2011; Miralles \& Rivero, 2012; Escribano-Miralles $\&$ Molina Puche, 2015).

However, there is still a long way to go in terms of promoting the experiences and forms of learning that make visits to both cultural and natural heritage sites possible (García-Marín, Martínez-Valcárcel, Espejo-Marín \& Paredes-Guerrero, 2016). According to the research carried out by these authors with high school students, heritage is perceived more as buildings, to the detriment of natural heritage, which was either rarely mentioned or in an imprecise manner. They also underlined the responsibility of the schools in these results, since it is the schools that are in charge of providing a comprehensive academic education on heritage, and that also includes the teachinglearning of responsible behaviour through cultural tourism.

Finally, another question that is interesting to comment on regarding the relationship between cultural tourism and teaching in relation to heritage, concerns the professional career of graduates with teaching degrees. According to Rivero (2006), those with a primary education speciality are the professionals who are better equipped to carry out work related to cultural tourism, and to work in museums or interpretation centres. Hence, it is essential that teachers of pedagogical degrees guarantee that future teachers have a solid training in the conservation and in the management of tangible and intangible heritage, as well as in the forms of cultural tourism that have emerged in recent years.

\subsection{Thematic cartography in the teaching of geography}

Society has come to consider having a detailed knowledge of the territory as essential if we are to address existing environmental and social problems in the current context of climate change. Cartography continues to be a fundamental tool for studying and interpreting these problems. Maps allow us to approach the different problems by taking into account the spatial realities which, in turn allows the design and development of sustainable models of territorial management (Luque Revuelto, 2011; Macía, RodríguezLestegás \& Armas, 2016; Martínez Murillo \& Delgado Peña, 2019).

However, the didactic use of maps is usually limited to their role as a support for locations, neglecting their potential to help us learn to think about space and acquire a command of geographic reasoning (Clary, 1992), two essential facets of teaching geography (Fontanabona, 2000). Thus, many students do not know how to extract and analyse information from maps and plans. This fact is related to a lack of teacher training in the use of cartography as a communication tool (Rodríguez-Lestegás, Macía \& Armas, 2017).

When considering cartography as an instrument for understanding the environmental, economic and social phenomena that occur at the territorial level, it is necessary to 
refer thematic cartography. It represents particular characteristics or concepts that show some phenomenon for which information is available (Membrado, 2015).

Thematic cartography is an extraordinary learning resource for the active, reflective and critical teaching of geography in the classroom (Macía, Rodríguez-Lestegás \& Armas, 2015). By using choropleth, chorochromatic, point, flow or diagram maps, the spatial realities at different territorial levels can be understood (Macía, RodríguezLestegás \& Armas, 2016). The potential of the thematic maps goes significantly beyond the traditional, informative approaches offered by most school text books in Spain, whose content is usually limited to physical and political maps and just a few topics that tend to cover population densities, migratory movements and professional occupations by industry sectors (Rodríguez-Lestegás, Macía \& Armas, 2017).

Moreover, school curricula barely pay any attention to cartography, and much less to thematic cartography (Macía, Rodríguez-Lestegás \& Armas, 2016). For example, a review of Royal Decree 126/2014 establishing the basic curriculum for Primary Education indicates that there are very few entries related to map content, and that thematic cartography is not explicitly mentioned at all (Real Decreto 126/2014).

In the case of Galicia, DECREE 105/2014, governing primary education in Galicia, does include cartography or thematic maps as a strategic resource for teaching geography. However, in fifth and sixth grades, years in which thematic maps are included, it is not specified which types (points, choropleths, flows) are the most appropriate to analyse the different demographic variables that the curriculum covers. Neither does it include the requirement to study correlations between maps to address such comprehensive issues as population aging, for example (DECRETO 105/2014).

Likewise, the primary education curriculum requires learning standards covering topics that are too complex in relation to the previous conceptual and analytical bases provided by the curriculum itself (Macía, Rodríguez-Lestegás \& Armas, 2016). For these reasons, the Atlas of the Information Society in Galicia (ASIG) offers a crucial strategic resource that allows the geography of Galicia to be presented, analysed and considered in years four and five of primary education (Armas \& Macía, 2014).

These identified deficiencies in the use of thematic cartography continue into the Galician secondary education curriculum. One can observe how the curriculum does not delve into the different types of maps offered by thematic cartography. Neither does it propose comparative mapping exercises, nor does it introduce correlations between maps. Likewise, it does not provide any links to any online resources for cartography, nor does it mention the usefulness of Geographic Information Systems (DECRETO 86/2015; Macía, Rodríguez-Lestegás \& Armas, 2017). 
It is precisely the purpose of this article to highlight the need for the integration of Information and Communication Technologies (ICT), Geographic Information Technologies (GIT) and thematic cartography in the teaching-learning of geography (Buzo Sánchez, 2015; De Miguel González, 2016; Membrado, 2016). In this way, students will acquire a series of skills that will satisfy the demands of the current labour market, and at the same time, generate new lines of work, in a critical and constructive spirit (Macía, Rodríguez-Lestegás \& Armas, 2017; Martínez Murillo \& Delgado Peña, 2019).

\section{METHODOLOGY}

The thematic cartography of Galicia that is presented in this article was prepared to be integrated into the Observatory of the Cultural Heritage of Galicia platform, which will be accessible through a website and an App (Figure 1). The purpose of the Observatory is allow both visitors and residents to visualise and evaluate Galician heritage. It also provides a valuable educational, heritage management and citizen participation tool. The Observatory is part of a project that is being developed within the framework of the R\&D Actions Agreement between the University of Santiago de Compostela and the Xunta de Galicia (2019-2020).

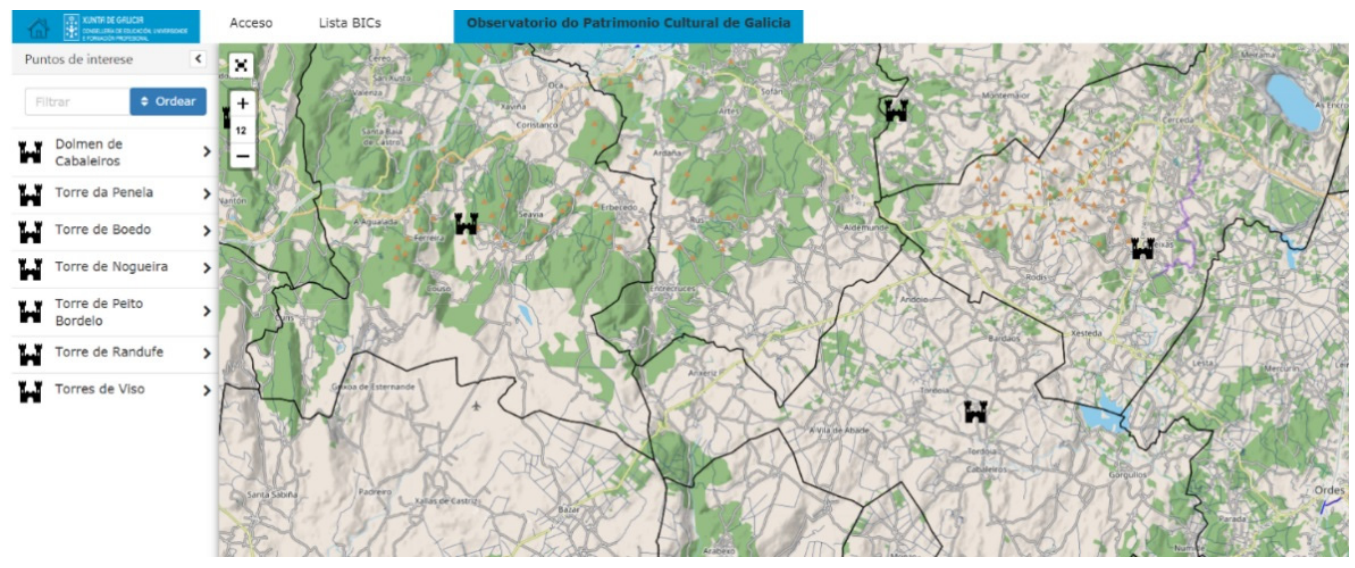

FiguRE 1. Preliminary version of the Observatory of the Cultural Heritage of Galicia Platform (USC, 2020).

The initial idea arose from the project "Cultural heritage of the Galicia-North of Portugal Euroregion: Assessment and Innovation (GEOARPAD)" (https://www. geoarpad.eu/es) of the European program INTERREG VA Spain Portugal (POCTEP). As a result of this project, a team from the University of Santiago de Compostela (USC) 
created the Heritage Information System for the Galicia-North Portugal Euroregion (Pérez Guilarte et al., 2020). The project compiled the following information for each heritage site (Figure 2): code, name, location, nature, degree of protection, category, publication decree, description, photos, bibliography. In addition, the System allows uploading of documentation, and has restricted access intended for the exclusive use of authorities with competence in heritage management.

Thematic cartography will form a part of the Observatory of the Cultural Heritage of Galicia platform where users will be able to configure the information they wish to consult, by displaying the different layers. At the same time, all the Observatory's resources will be integrated into the Digital Atlas of the Cultural Heritage of Galicia, which will be accessible from the Observatory's own platform. The thematic maps will allow knowledge about Galician heritage to be combined with the main demographic and socioeconomic dynamics that take place in Galicia, offering a more complete view of its culture and geography.

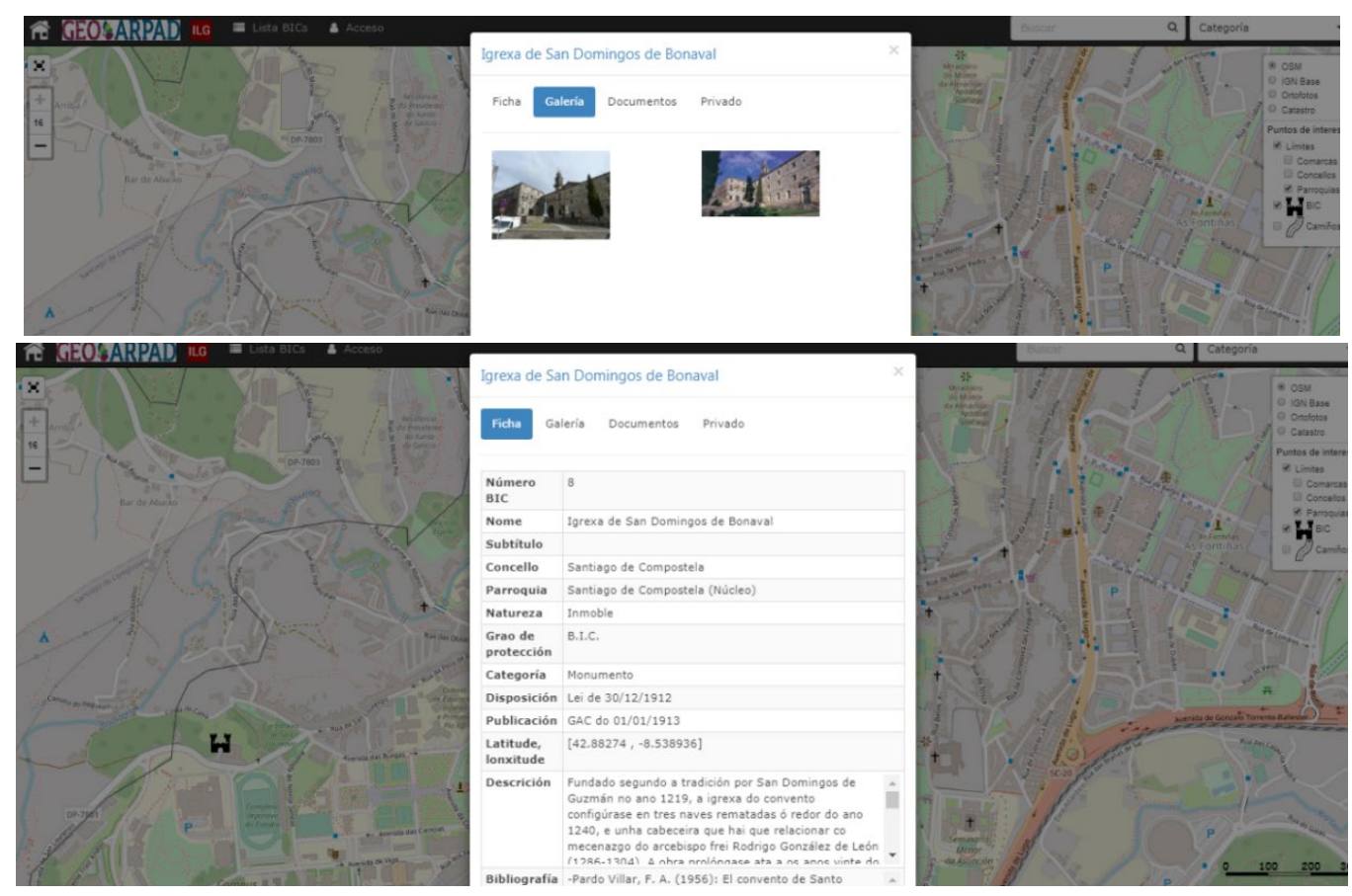

FIgURE 2. Heritage Information System of the Galicia-Northern Portugal Euroregion Platform (GEOARPAD, 2020) 


\section{THEMATIC CARTOGRAPHY OF GALICIA}

The cartography that will make up the platform of the Observatory of the Cultural Heritage of Galicia includes an initial group of thematic maps at the level of parishes or municipalities using point maps or choropleths. The cartographic base of the Infrastructure of Spatial Data of Galicia (IDEG) of the Institute for Territory Studies of the Xunta de Galicia was used for the elaboration of the maps. In the case of Galicia, cartography at the parish level is particularly relevant since it makes it possible to study the more than 3,000 existing parishes in depth. On the one hand, maps were made to represent the Sites of Cultural Interest (BIC is its acronym in Spanish) of Galicia, in particular buildings and monuments. On the other hand, thematic maps that include demographic and socioeconomic aspects of Galicia such as population density, mortality and birth rates, aging index, population employed in the tertiary sector, and population with tertiary studies, were created.

\subsection{Heritage-themed maps as a teaching aid}

According to LAW 5/2016, the cultural heritage of Galicia includes movable, immovable and intangible forms that, due to their artistic, historical, architectural, archaeological, paleontological, ethnological, anthropological, industrial, scientific and technical, documentary or bibliographic value, must be considered of interest for maintaining the permanence, recognition and identity of Galician culture over time (LEY 5/2016).

There are a total of 741 declared BICs and 27 are in the process of initiation, as of May $25^{\text {th }} 2020$ (Xunta de Galicia, 2020). It is interesting to note that intangible heritage represents just $1.5 \%$ of the total declared assets, among which are festivals, and building and craft techniques, and the legacy of Alfonso Daniel Manuel Rodríguez Castelao, emblematic figure of Galician culture of the $20^{\text {th }}$ century. Likewise, movable cultural heritage makes up $3 \%$ of the BICs, included under the categories of individual works or collections. The immovable heritage, on the other hand, is classified into the following categories: monuments, historical gardens, historical sites, archaeological sites or zones, cultural routes, places of ethnological value, historical centres, cultural landscapes and historical territories.

The Cultural Heritage Observatory platform, in its first phase, includes only immovable cultural heritage sites that had been catalogued up until December 2018, a total of 679 . Currently the list has 708 immovable cultural heritage sites. This difference of 29 sites is due to the fact that these locations were not available at the time the cartography was drawn up, and they will be included in subsequent phases. To integrate the sites into the Observatory platform, they were grouped into the following four categories, as shown in Table 1: monuments, archaeological assets, historical-cultural sites and historical centres. 
LAW 5/2016 Categories

Monuments

Historical centres

Historical gardens

Historic places

Cultural routes

Places of ethnological value

Cultural landscapes

Historical territories
GEOARPAD Categories

Monuments

Historical centres

Historical - cultural sites
Archaeological assets

TABLE 1. Regrouping of immovable BIC categories. Source: Own creation.

This regrouping was previously carried out in the GEOARPAD project, with the aim of harmonising the categories of Galicia with those of the heritage categories of Portugal. However, it was decided to keep these four categories instead of the nine established by LAW 5/2016 to avoid a high dispersion of georeferenced data. Therefore, four thematic maps were made at the parish level corresponding to each of these categories. They were grouped into a single map for presentation in this article, due to a limitation in the maximum article length (Figure 3).

As Figure 3 shows, conclusions can be drawn regarding the weight of each category and its distribution. The historical places and the historical-cultural sites have a low representation in relation to the overall immovable heritage. On the other hand, the monuments are the most numerous and are distributed more equally throughout the Galicia. Meanwhile, the archaeological sites have a marked concentration in the Atlantic coastal zone, particularly in the province of Pontevedra.

These heritage-themed maps will be integrated into the platform as part of the Digital Atlas of the Cultural Heritage of Galicia along with the other thematic maps. The Atlas is designed for educational purposes, since it will allow teachers to work with content related to the historical, natural and cultural heritage of Galicia in the classroom in social science subjects at different educational levels. Likewise, it may serve as a reference when preparing teaching units and other educational content on this subject. 


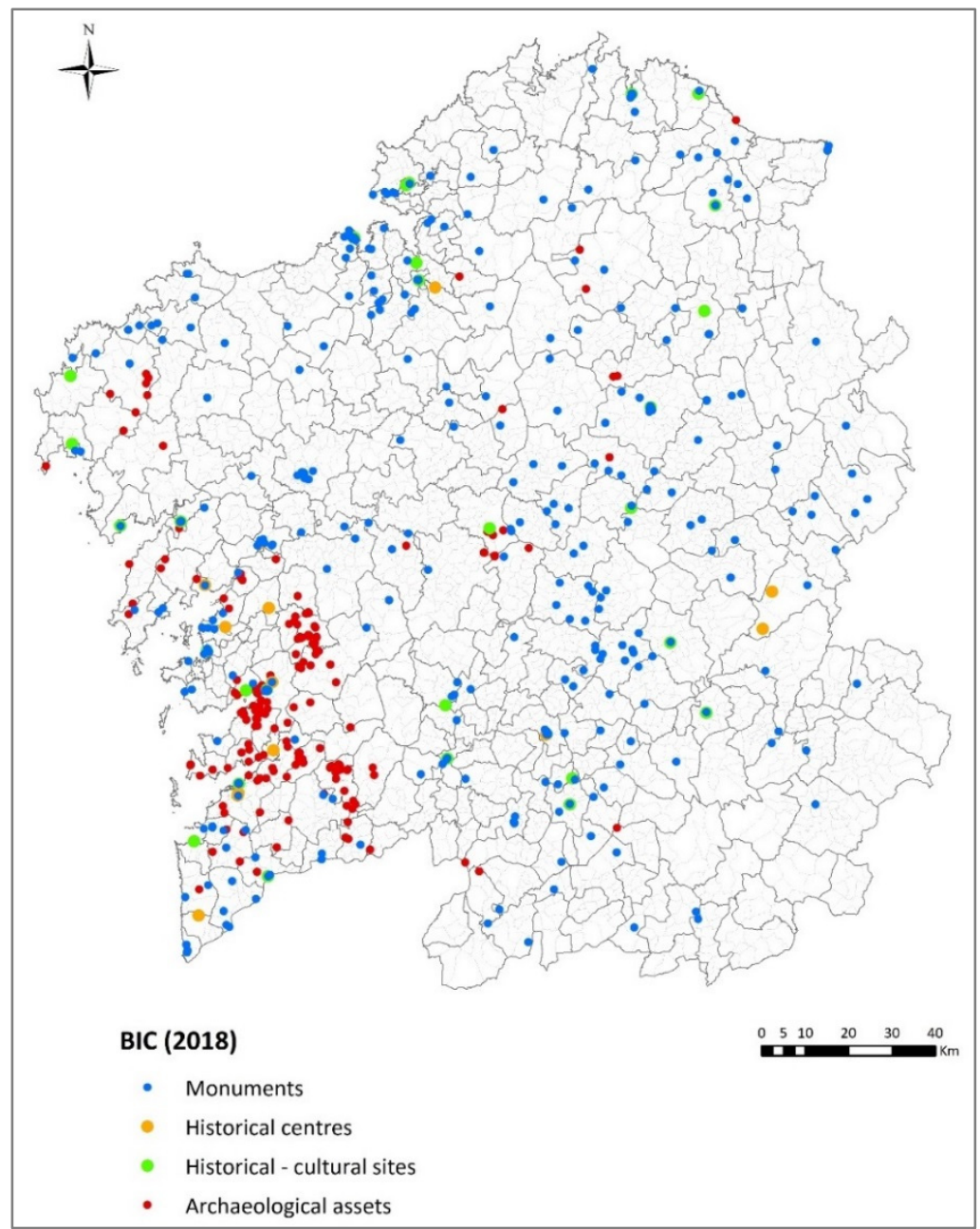

FIGURE 3. Sites of Cultural Interest in Galicia (BIC). Own creation based on Xunta de Galicia figures (Xunta de Galicia, 2018)

\subsection{Demographic and socioeconomic maps to teach about the territory}

The maps related to demographic and socioeconomic themes will form part of the Digital Atlas of the Cultural Heritage of Galicia and will be integrated as thematic layers into the Observatory of the Cultural Heritage of Galicia platform. The maps related to population density by parish, aging index and population employed in the tertiary sector are presented below as an example of a teaching aid to learn about the territory. 
Figure 4 shows how Galicia is defined by a strong contrast in demographic densities between the more urbanized coastal areas of western Galicia and inland Galicia. Thus, five of the seven main cities are located in the so-called Atlantic Urban Axis, which occupies 5,000 to $7,000 \mathrm{~km}^{2}$, and more than 2 of the 2.7 million registered Galicians reside there. The economic and demographic importance of the cities of Vigo (295,364 inhabitants) and A Coruña (245,711 inhabitants) must be highlighted (IGE, 2020). The role of the urban area of Santiago de Compostela is also important, reinforcing the continuity of the urban areas and densification along a corridor in a North-South direction. The Mariña Lucense corridor (Viveiro, Burela, Foz, Ribadeo) also clearly stands out.

On the contrary, the rest of Galicia has undergone an intense depopulation process over decades and its municipalities generally have fewer than $50 \mathrm{inhab} / \mathrm{km}^{2}$. Only those territories in which the provincial capitals of the interior are located (Lugo and Ourense), their peripheries, and the town councils centralized around a town or small city have somewhat higher levels of occupation. There is a population crisis with extreme levels of depopulation in the high mountain areas, in areas of significant altitude differences and in the remotest areas, where the figures are often no longer even as high as 20 inhabitants $/ \mathrm{km}^{2}$.

In Galicia, the overall population has been stagnant for a long time; the number of deaths exceeds that of births and the average age of the population is increasing, expressing indisputable symptoms of aging, although it is true that Spain has the third longest life expectancy in the world. Some of the factors that have led to this situation are the massive waves of emigration abroad, the lack of employment and job prospects for the young population, and the decline in fertility rates caused by the generalization of family planning (López, 2013; Guisán \& Cancelo, 2018). However, the situation differs depending on the geographical area (Martínez \& Peón, 2015), as the map in Figure 5 clearly shows. The Atlantic urban axis has lower aging index figures, compared to inland Galicia. This pattern corresponds to the territorial differences in population density explained above.

The intense urbanization and concentration of population near the coast is explained by the fact that the most profitable economic activities and those that generate the most employment are located in these areas (Guisán \& Cancelo, 2018). 60\% of companies and three-quarters of GDP are concentrated in the regions around the 5 cities in the Axis, with the undisputable primacy of the areas of Vigo and A Coruña. They account for a large part of the major industries and foreign trade through the ports. In Vigo, the contribution of the automobile sector is significant, especially that of the Groupe PSA automobile factory and its subsidiary companies. The cluster of firms linked to maritime and fishing activities such as shipowners, refrigeration plants, agri-food factories and shipyards is also considerable. In A Coruña, the chemical and metal industries and the textile sector, with the presence of the ZARA-Inditex plant, form a very powerful manufacturing base. 
The thematic cartography of Galicia as a promoter of cultural tourism and as a teaching aid...

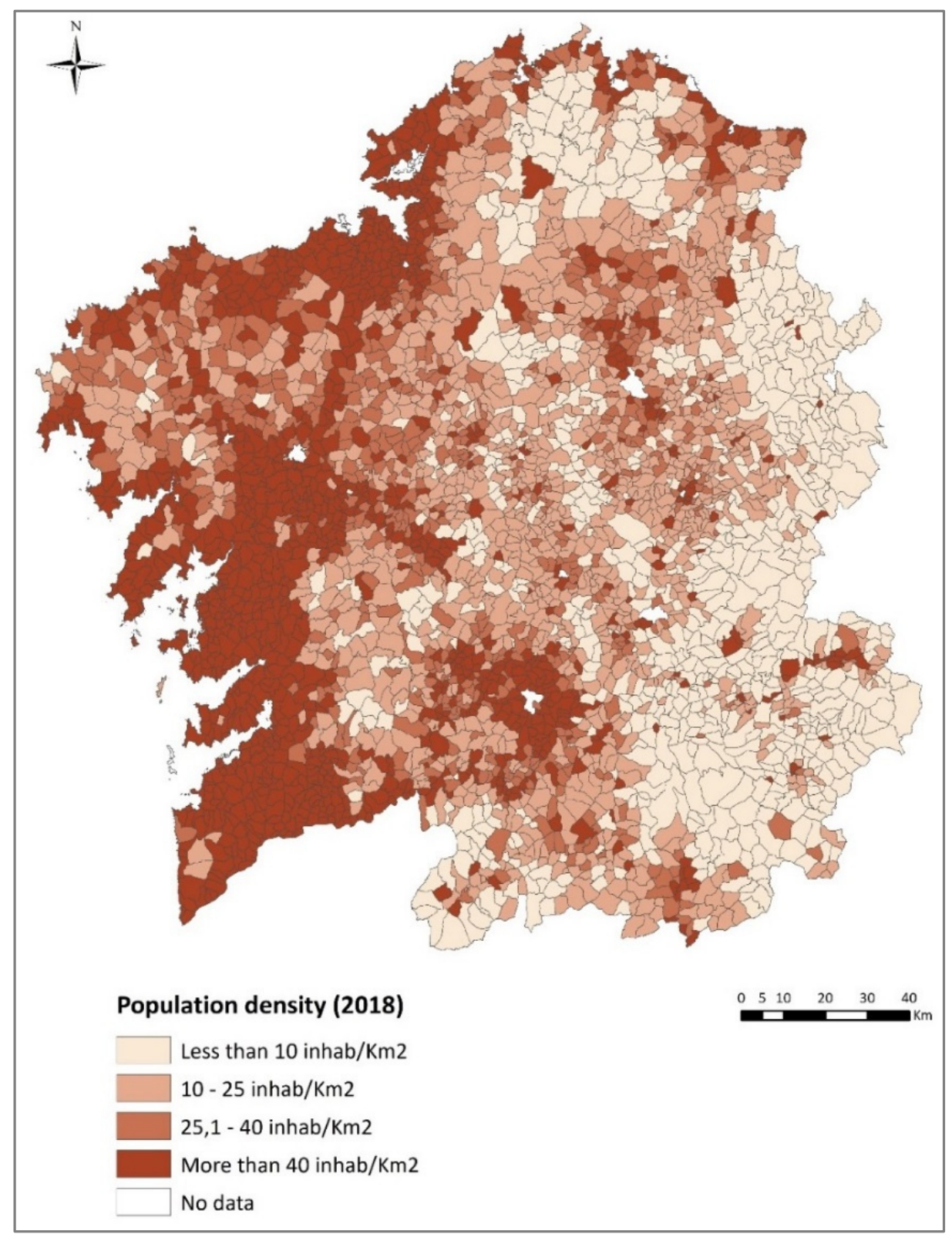

FIGURE 4. Population density by parishes. Own creation based on Galician Institute of Statistics figures (IGE, 2018) 


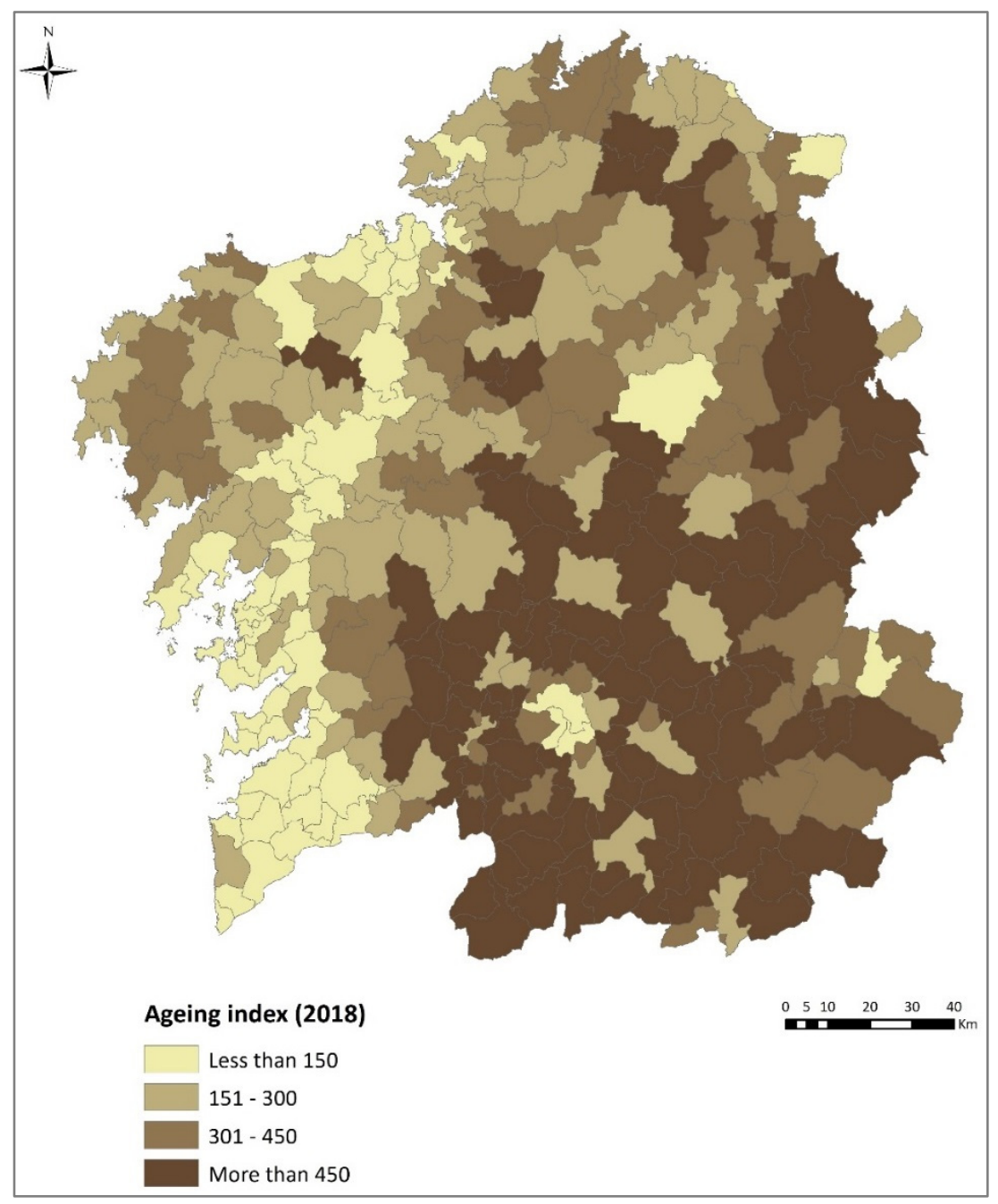

FIGURE 5. Ageing index. Own creation based on Galician Institute of Statistics figures (IGE, 2018)

Likewise, in the areas of Vigo and A Coruña there is also a group of tertiary activities that define the socioeconomic complexity of Galicia, from large shopping centres and thousands of shops to state-of-the-art hospitals, universities and a group of technological and innovation clusters. However, the tertiary sector is also of significant importance in the other major Galician cities and their surrounding areas. As Figure 6 shows, a large part of them employs more than $50 \%$ of the population. In the Santiago de Compostela area this is particularly notable, due to the volume of services that have emerged to satisfy the strong tourism business. 


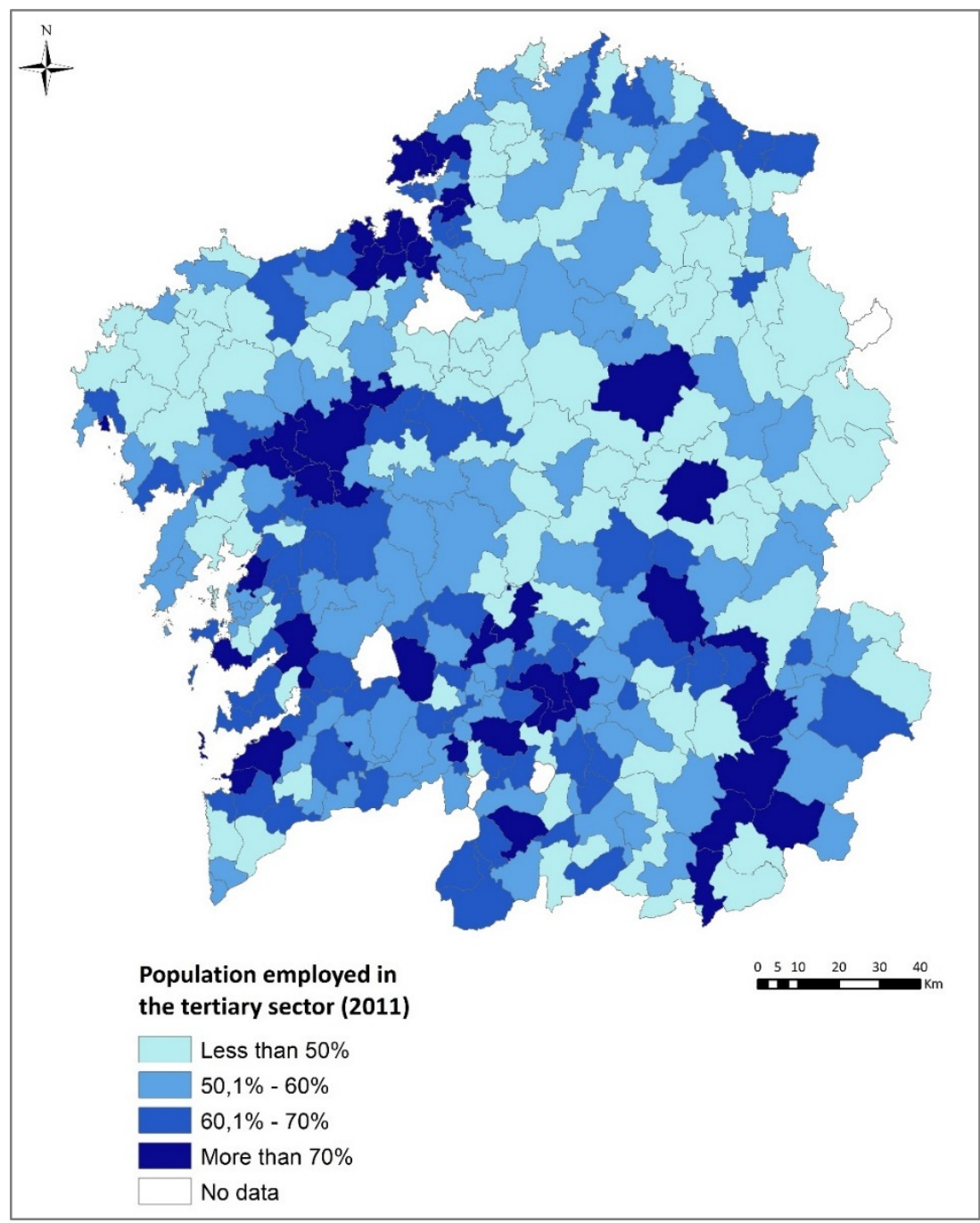

FIGURE 6. Population employed in the tertiary sector. Own creation based on Galician Institute of Statistics figures (IGE, 2011)

The thematic cartography described in this section would allow visitors to complete the information about cultural heritage with demographic and socioeconomic data, which is of great relevance in the current context. For example, knowing which are the least populated areas can be decisive when selecting a tourist destination. We are experiencing a reshaping of tourism where, in addition to the attractiveness of the place for health and safety reasons - it will also be important that they are not places with large concentrations of people. 
In the educational field, these thematic maps offer teachers the possibility of approaching the curricular contents related to demography and economic sectors from a spatial perspective. They also offer the possibility of establishing correlations between different maps to facilitate understanding of complex aspects such as population aging.

\section{CONCLUSIONS}

Currently, society is facing a process involving the reshaping of a large part of social, cultural, educational and economic activities, due to the effects caused by the COVID-19 pandemic. In this context, Information and Communication Technologies and Geographic Information Technologies are beginning to play an even greater role than they already do in our daily activities. From the point of view of cultural tourism, the Observatory of the Cultural Heritage of Galicia platform offers visitors valuable information that will allow them to plan tourist routes in advance according to their interests. In particular, for pilgrims following the Way of Saint James, the App could be a very useful tool, since they will be offered information on the heritage sites and the territory located along their route.

In addition, it should be noted that the Observatory of the Cultural Heritage of Galicia platform is a tool designed to provide public bodies with sustainable heritage and territorial management possibilities, including citizen participation. It should also be highlighted that the thematic maps presented in this article represent the first example of the thematic cartography that will form part of the Observatory platform, which will continue to be enriched over subsequent phases.

From an educational perspective, having a heritage information platform into which thematic maps have been integrated, will become a vital teaching resource for the teaching-learning of the geography of Galicia. Its role is particularly important for the active, reflective and critical practice of geography, a requirement from primary education through to university. Moreover, thematic cartography provides an excellent teaching aid in education for leisure and free time from a heritage and territorial perspective, an essential strategy in the comprehensive training of socially and environmentally responsible citizens.

\section{REFERENCES}

Armas Quintá, F. X., \& Macía Arce, X. C. (2014). Atlas. A Sociedade da Información en Galicia. Manual de cartografía para a aprendizaxe, ensinanza e xestión do territorio. Santiago de Compostela: Andavira.

Asensio, M., \& Pol, E. (2002). Nuevos escenarios en educación. Aprendizaje informal sobre el patrimonio, los museos y la ciudad. Buenos Aires: Aique. 
The thematic cartography of Galicia as a promoter of cultural tourism and as a teaching aid...

Benejam, P., \& Tomàs, C. (2003). Los objetivos de las salidas. Iber. Didáctica de las Ciencias Sociales, Geografía e Historia, 36, 7-12. Retrieved from https://www. grao.com/es/producto/los-objetivos-de-las-salidas

Buzo Sánchez, I. (2015). Posibilidades y límites de las TIC en la enseñanza de la geografía.Ar@cne: revista electrónica de recursos en internet sobre geografía y ciencias sociales, 195, April, 1-21. Retrieved from http://www.ub.edu/geocrit/ aracne/aracne-195.pdf

Chang, L., Backman, K.F., \& Chih Huang, Y. (2014). Creative tourism: a preliminary examination of creative tourists' motivation, experience, perceived value and revisit intention. International Journal of Culture, Tourism and Hospitality Research, 8 (4), 401-419. https://doi.org/10.1108/IJCTHR-04-2014-0032

Clary, M. (1992). Aprender a situar, situar para aprender. Boletín de didáctica de las ciencias sociales, 5, 31-43. Retrieved from http://didactica-ciencias-sociales.org/ wp-content/uploads/2019/01/5-1992.pdf

De Miguel González, R. (2016). Espacio digital y educación geográfica. El Atlas Digital Escolar. In Ciencias Sociales, educación y futuro. Investigaciones en didáctica de las ciencias sociales (pp. 1148-1159). Libro de Actas del VII Simposio Internacional de Didáctica de las Ciencias Sociales en el ámbito Iberoamericano. Santiago de Compostela, $2^{\text {nd }}-4^{\text {th }}$ Novembre, 2016. Retrieved from http:// www.7 simposiodcs.com/

Decreto $105 / 2014$, of September $4^{\text {th }}$, which establishes the primary education curriculum in the Autonomous Community of Galicia. Diario Oficial de Galicia. Santiago de Compostela. September $9^{\text {th }}, 2014$, num. 171, pp. 37406 - 38087. Retrieved from https://www.edu.xunta.gal/portal/sites/web/files/protected/content type/ advertisement/2014/09/09/20140909 curriculo primaria.pdf

Decreto $86 / 2015$, of June $25^{\text {th }}$, which establishes the curriculum of compulsory secondary education and high school in the Autonomous Community of Galicia. Diario Oficial de Galicia. Santiago de Compostela. June 29 $9^{\text {th }}$, 2015, num. 120, pp. 25434 - 27073. Retrieved from https://www.xunta.gal/dog/Publicados/2015/20150629/ AnuncioG0164-260615-0002 es.pdf

Escribano-Miralles, A., \& Molina Puche, S. (2015). La importancia de salidas escolares y museos en la enseñanza de las ciencias sociales en Educación Infantil. Análisis de un caso a partir del modelo CIPP. CLIO. History and History teaching. (Art.\#2015_20). Retrieved from http://clio.rediris.es/n41/articulos/ EscribanoMolina2015.pdf

Fontanabona, J. (Dir.) (2000). Cartes et modèles graphiques: analyses de pratiques en clase de géographie. Paris: Institut National de Recherche Pédagogique. 
García-Marín, R., Martínez-Valcárcel, N., Espejo-Marín, C., \& Paredes-Guerrero, A. (2016). Patrimonio, educación y turismo responsable: la importancia del conocimiento del patrimonio tras los estudios de bachillerato. In R. Sebastiá Alcaraz \& E. María Tonda Monllor (Coord.), La investigación e innovación en la enseñanza de la geografía (pp. 71-86). San Vicente del Raspeig: Universidad de Alicante. Retrieved from http://didacticageografia.age-geografia.es/docs/ Publicaciones/2015 Congreso Iberico.pdf

GEOARPAD (2020). Cultural Heritage of the Galicia-Northern Portugal Euro-region: Enhancement and Innovation. Xunta de Galicia. Retrieved from https://tec.citius. usc.es/geoarpad/bootleaf-master/

Guisán, M. C. \& Cancelo, M. (2018). Principais indicadores económicos de Galicia: 50 anos de evolución da produción e do emprego, 1967-2017. Revista Galega de Economía, 27-3,1-27. Retrieved from https://revistas.usc.gal/index.php/rge/ article/view/5432

Hodkinson, P. Colley, H. \& Malcolm, J. (2003). The interrelationship between informal and formal learning. Journal of Workplace Learning, 15, 7/8, 313-318. https://doi. org/10.1108/13665620310504783

IGE (2011). Pobación ocupada de 16 e máis anos segundo a rama de actividade. Instituto Galego de Estadísticas. Retrieved from https://www.ige.eu/igebdt/selector.jsp?C OD $=7122 \&$ paxina $=001 \& \mathrm{c}=0204032$

IGE (2018). Indicadores de poboación. Instituto Galego de Estadísticas. Retrieved from https://www.ige.eu/igebdt/selector.jsp?COD $=723 \&$ paxina $=002001 \& \mathrm{c}=0201004$

IGE (2020). Cifras oficiais da poboación a 1 de xaneiro. Ano 2019. Instituto Galego de Estadísticas. Retrieved from https://www.ige.eu/web/mostrar_actividade estatistica.jsp?idioma $=$ gl\&codigo $=0201001002$

Ley 5/2016, of May $4^{\text {th }}$, on the cultural heritage of Galicia. Diario Oficial de Galicia. Santiago de Compostela. May 16 ${ }^{\text {th }}$, 2016, num. 92, pp. 18576 - 18689. Retrieved from https://www.xunta.gal/dog/Publicados/2016/20160516/ AnuncioC3B0-110516-0001 es.pdf

López, E. (2013). A gobernanza e xestión do medio rural galego a comezos do século XXI: Reflexións e propostas para o debate. In En R. Rodríguez González (Coord.), Galicia, un mundo rural Vivo (pp. 130-147). Lalín: UIMP - Concello de Lalín.

Luque Revuelto, R. M. (2011). El uso de la cartografía y la imagen digital como recurso didáctico en la enseñanza secundaria. Algunas precisiones en torno a Google Earth. Boletín de la Asociación de Geógrafos Españoles, 55, 183-210. Retrieved from https://bage.age-geografia.es/ojs/index.php/bage/article/view/1318/1241 
The thematic cartography of Galicia as a promoter of cultural tourism and as a teaching aid...

Macía, X.C., F. Rodríguez-Lestegás \& F.X. Armas (2015). Manual de aprendizaxe e ensinanza de xeografía e ciencias sociais para educación secundaria. Santiago de Compostela: Andavira.

Macía, X.C., F. Rodríguez-Lestegás \& F.X. Armas (2016). La cartografía temática como recurso didáctico en los procesos de enseñanza y aprendizaje de las ciencias sociales para educación primaria. Revista Brasileira de Educação em Geografia, 6 (11), 428-438. Retrieved from http://www.revistaedugeo.com.br/ojs/index.php/ revistaedugeo/issue/view/15

Macía, X.C., F. Rodríguez-Lestegás \& F.X. Armas (2017). Cartografía temática y recursos TIC en la enseñanza y aprendizaje de la Geografía regional de Europa. Revista de Investigación en Didáctica de las Ciencias Sociales, 1, 71-85. https:// doi.org/10.17398/2531-0968.01.71

Martínez Murillo, J.F., \& Delgado Peña, J.J. (2019). Análisis de las guías docentes de las asignaturas de cartografía en los actuales grados de geografía en España. Didáctica Geográfica, 20, 79-93. https://doi.org/10.21138/DG.456

Martínez, X. \& Peón, D. (2015). Patróns de despoboamento do rural galego: unha análise por comarcas. Revista Galega de Economía, 24-1, 63-80. Retrieved from https:// revistas.usc.gal/index.php/rge/article/view/2698

Membrado, J. C. (2016). Innovación en la docencia geográfica universitaria: mapas temáticos y SIG. In R. Sebastiá Alcaraz \& E. María Tonda Monllor (Coord.), La investigación e innovación en la enseñanza de la geografía (pp. 625-640). San Vicente del Raspeig: Universidad de Alicante. Retrieved from http:// didacticageografia.age-geografia.es/docs/Publicaciones/2015 Congreso Iberico. pdf

Membrado, J. C., (2015). El lenguaje cartográfico en los mapas temáticos. Estudios Geográficos, 76 (278), 177-201. Retrieved from http://estudiosgeograficos. revistas.csic.es/index.php/estudiosgeograficos/article/view/448/448

Miralles, P., \& Rivero,P. (2012). Propuestas de innovación para la enseñanza de la historia en Educación Infantil. Revista Electrónica Interuniversitaria de Formación del profesorado (REIFOP), 15 (1), 81-90. Retrieved from: https://www.redalyc.org/ articulo.oa?id=2170/217024398006

Molina Puche, S. (2010). El museo "La Casa Encantada” de Briones en la enseñanza de la Historia: propuesta para una salida escolar para Educación Primaria. Contextos Educativos, 13, 71-82. Retrieved from https://publicaciones.unirioja.es/ojs/index. $\mathrm{php/contextos/article/view/627/590}$

Molina Puche, S. (2011). Las salidas escolares para la enseñanza de la Historia en Educación Primaria: análisis de su uso en la Comunidad Autónoma de La 
Rioja. Iber. Didáctica de las Ciencias Sociales, Geografía e Historia, 67, 79-86. Retrieved from https://www.grao.com/es/producto/las-salidas-escolares-para-laensenanza-de-la-historia-en-educacion-primaria

Pérez Guilarte, Y., \& Lois González, R. C. (2018). Sustainability and visitor management in tourist historic cities: the case of Santiago de Compostela, Spain. Journal of Heritage Tourism, 13 (6), 489-505. https://doi.org/10.1080/174387 $\underline{3 X .2018 .1435665}$

Perez Guilarte, Y.; Lois González, R. C., Armas Quintá, F. X., Macía Arce, X. C. (2019). Heritage Information System to Promote Cultural Tourism and the Use of Digital Mapping in Primary and Secondary School. In Cultural and Tourism Innovation in the Digital Era. Sixth International IACuDiT Conference, Athens 2019, (pp. 1735). Springer Proceedings in Business and Economics. Cham: Springer Nature. https://doi.org/10.1007/978-3-030-36342-0_2

Real Decreto 126/2014, of February 28 ${ }^{\text {th }}$, which establishes the basic curriculum of Primary Education. Boletín Oficial del Estado. Madrid. March 1 ${ }^{\text {st }}, 2014$, num. 52, pp. 19349 - 19420. Retrieved from https://www.boe.es/boe/dias/2014/03/01/pdfs/ BOE-A-2014-2222.pdf

Richards, G. (2018). Cultural tourism: A review of recent research and trends. Journal of Hospitality and Tourism Management, 36, 12-21. https://doi.org/10.1016/j. jhtm.2018.03.005

Rivero,P.(2006). Didáctica de las Ciencias Sociales fuera de la escuela: competencias para una mayor empleabilidad. In IV Congrés Internacional Docència Universitària Innovació "La competència docent". Barcelona July $5^{\text {th }}-7^{\text {th }}$, 2006. Retrieved from http://www.ub.edu/histodidactica/index.php?option=com content\&view=ar

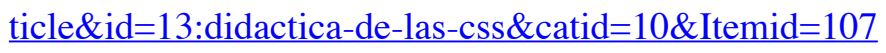

Rodríguez-Lestegás, F., Macía-Arce, X. C., \& Armas-Quintá, F. X. (2017). El lenguaje cartográfico en la formación del profesorado de educación secundaria. In Atas do VIII Congreso Ibérico de Didáctica da Geografía. Educação Geográfica na Modernidade Líquida (pp. 396-409). Lisbon, October $12^{\text {nd }}-14^{\text {th }}, 2017$. Retrieved from http://www.didacticageografia.age-geografia.es/docs/Publicaciones/2017 VIII\%20Congresso Iberico.pdf

Ruiz, E., Hernández, M., Coca, A., Cantero, P., \& Del Campo, A. (2008). Turismo comunitario en Ecuador. Comprendiendo el community-based tourism desde la comunidad. Pasos, 6 (3), 399-418. https://doi.org/10.25145/j.pasos.2008.06.031

Smith, W. L. (2006). Experiential tourism around the world and at home: definitions and standards. International Journal of Services and Standards, 2 (1), 1-14. https:// doi.org/10.1504/IJSS.2006.008156 
The thematic cartography of Galicia as a promoter of cultural tourism and as a teaching aid...

UNWTO (2018). Report on Tourism and Culture Synergies. Madrid: UNWTO. Retrieved from https://www.e-unwto.org/doi/pdf/10.18111/9789284418978

USC (2020). Activities Report 2019. Development of the heritage information management platform defined in GEOARPAD project. $R \& D$ Actions Agreement Project (Xunta 2019-2020). Unpublished manuscript.

Xunta de Galicia (2018). Bienes de Interés Cultural. In Datos abertos da Xunta de Galicia. Retrieved from https://abertos.xunta.gal/catalogo/cultura-ocio-deporte/-/ dataset/0375/bens-interese-cultural-bic

Xunta de Galicia (2020). Bienes de Interés Cultural. In Datos abertos da Xunta de Galicia. Retrieved from https://abertos.xunta.gal/catalogo/cultura-ocio-deporte/-/ dataset/0375/bens-interese-cultural-bic 